\title{
Performance Assessment of the Secretariat of the Electoral Commission of Tanah Bumbu Regency, South Kalimantan
}

\author{
Makhruri $^{1}$, Budi Suryadi ${ }^{2 *}$, Jamaluddin ${ }^{3}$ \\ ${ }^{1}$ Master of Government Science Students, Lambung Mangkurat University, Indonesia \\ ${ }^{2,3}$ Faculty of Social Science and Political Science, Lambung Mangkurat University, Indonesia
}

DOI: $10.36348 /$ sijlcj.2021.v04i01.001

| Received: 08.01.2021 | Accepted: 19.01.2021 | Published: 22.01.2021

*Corresponding author: Budi Suryadi

\section{Abstract}

Performance assessment of the secretariat apparatus of the regional election commission on operational implementing elements that have the task of carrying out some of the technical tasks of election operations based on The Electoral Commission Regulation No. 22 of 2008 on organizational structure and working procedures of the Secretariat of the Electoral Commission. The method used in this research is qualitative method. Data collection techniques are carried out using participatory observations, interviews and documentation studies. Data analysis is done with descriptive techniques through three flow of activities that are one unity, namely: data reduction, data presentation and conclusion drawing. The results showed that the performance assessment of the secretariat apparatus of the regional election commission tends to show performance on quantity, quality and timeliness despite constraints on employee discipline and efficiency of target achievement.

Keywords: Performance apparatus, secretariat, regional election commission.

Copyright () 2021 The Author(s): This is an open-access article distributed under the terms of the Creative Commons Attribution 4.0 International License (CC BY-NC 4.0) which permits unrestricted use, distribution, and reproduction in any medium for non-commercial use provided the original author and source are credited.

\section{INTRODUCTION}

The implementation of regional autonomy has brought demands and changes to the value system and work culture in the administration. The implementation of regional autonomy demands basic values that can always accommodate the needs oriented to the aspirations of the community with the principles of democratization, equality and justice.

The condition requires a structured frame of mind to be able to empower public functions to better suit the demands of economic, political, social and cultural development. Therefore, it is necessary to improve the culture and work ethic that is oriented towards achieving results and accountability based on the values of accountability towards good governance, namely to achieve performance in accordance with expectations.

The implementation of programs and activities of the Electoral Commission in the framework of the implementation of functions and achievements of performance is financed by the State Budget in accordance with Government Regulation No. 90 of 2010 concerning the Preparation of Work Plans and Budgets of the Ministry of State / Institution. As an institution that uses the state budget in the implementation of its duties and activities as well as institutions that put forward a system of openness, transparency, accountability and accountability.

Tanah Bumbu Regency Election Commission is an operational implementing element that has the task of carrying out some of the operational, technical tasks of elections based on The General Election Commission Regulation No. 22 of 2008 concerning the Organizational Structure and Working Procedures of the Secretariat of the Electoral Commission is one of the parts that has the task of carrying out technical affairs of elections and public participation relations.

The performance of the secretariat apparatus of the Tanah Bumbu Regency Election Commission is required to be more optimal in carrying out its duties and functions. The Tanah Bumbu Regency Election Commission is currently actively making efforts in order to improve performance in various ways, one of which is by paying attention to the ability to carry out tasks.

Then from the temporary observations showed the Election Commission of Tanah Bumbu Regency in carrying out the main task still has obstacles, among others: 
1. Not optimal personnel resources, because there is still a lack of apparatus to fill the existing parts, so that competency improvement services have not touched the competency improvement of commissioners, secretaries and sub-section heads;

2. Human resources are still lacking, while the working area is very large;

3. The availability of permanent office buildings and office devices and infrastructures are still very minimal.

The importance of the performance of the secretariat apparatus of the Tanah Bumbu Regency Election Commission, can certainly provide and provide information to the community and stakeholders of all government activities that will and are being carried out. The main task of the Tanah Bumbu Regency Election Commission is to collect and manage the technical materials for organizing elections and regional head elections.

Performance assessment research at the Regional Disaster Management Agency on flood disaster prevention and preparedness from the aspect of understanding the auth and aspects of work accuracy tends to be many activities in the field of disaster prevention and preparedness carried out compared to aspects of innovation, speed of work and cooperation [1].

Performance building indicators vary greatly according to the focus and context of the research carried out. For example, responsiveness indicators to measure providers' responsiveness to consumer expectations, wants and aspirations and demands; the responsibility of a measure that shows how far the process of providing public services is done by not violating the provisions that have been set; accountability of a measure that shows how much conformity between service providers and external measures that exist in the community and are owned by stakeholders [2].

Then an employee performance assessment tends to consider the following: quantity, i.e. The amount to be completed or achieved; quality, i.e. The quality that must be produced (whether or not). Qualitative measurement of the output reflects the measurement or the level of satisfaction that is how good the solution is; punctuality, i.e. In accordance with the planned time [3]. Performance assessment is very important because with it can be used to know the performance of the organization. By assessing performance, efforts to improve performance can be done more targeted and systematically [4].

\section{RESEARCH METHODS}

The approach that will be used in the performance research apparatus of the Tanah Bumbu Regency Election Commission is a qualitative approach which is a process of research and understanding based on a methodology that investigates a social phenomenon and human problems. In this approach, researchers create a complex picture, examine words, report detailed from the informant's view, and conduct studies on natural situations. Bogdan and Taylor suggest that qualitative method is a research procedure that produces descriptive data in the form of written and spoken words from people and observed behavior [5]

Data collection techniques are carried out based on participatory observations through careful direct observation in the field, interviews are used to obtain primary data through unstructured interview techniques, and documentation studies in the form of document studies related to the main duties and functions of the Electoral Commission secretariat.

Data analysis as a process of systematically searching and compiling data obtained from interviews, field records and documentation so that it is easy to understand and its findings can be informed to others. Data analysis using interactive analysis of data collection, data reduction, data presentation and inference and verification [6].

The data process that has been stated, is carried out continuously by studying the data, grouping the data, finding what is important in accordance with the research problems and studying and deciding what to report. Through this analysis is attempted to reveal what data still needs to be searched, what questions to answer, what ways to update. As for the matrices of interactive data analysis, as follows:

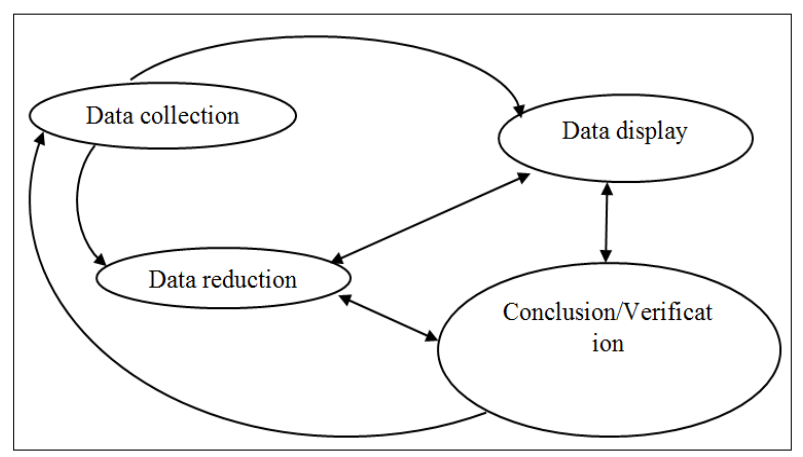

\section{RESULTS AND DISCUSSION}

Performance assessment of the secretariat apparatus of the Tanah Bumbu Regency Election Commission includes several criteria, as follows:

First, quantity. The quantity of this work relates to the number/volume of tasks (jobs) completed at the specified time. The quantity of work can be obtained from the results of work measurement or participatory goal setting. Determination of work quantity can be done through discussions between superiors and subordinates, where the discussion 
material includes job objectives, their role in relationships with other jobs, organizational requirements, and employee needs.

Thus, this quantity aims to determine how many personnel and how many responsibilities or workloads can be delegated to an employee. In determining the quality of work that must be done is to identify both the number of employees and the qualifications of work needed to achieve the objectives of the organization.

To get good work in an organization, one of the elements that must be considered is that the organization must be able to manage between the number / volume of work with a predetermined period of time in other words the other tasks do not interfere with each other. When it comes to other things, the other tasks don't interfere with each other. Concerning the arrangement between the volume (quantity) of work and the timeframe / schedule that has been found.

The number of employee jobs is completed based on a set schedule, where the jobs do not conflict with each other's schedules because they are already listed in each employee's workload so that more work programs are carried out. And inseparable from the number of employees who have been determined to work on each work goal divided by each, so that the number of workloads with the number of employees who work can be balanced so that each job can be completed according to the schedule. So for the completion of duties and responsibilities is good enough.

Second, quality. Every employee in the Tanah Bumbu Regency Election Commission has worked or carried out their duties in accordance with the orders of the superiors. Superiors here also play an important role in achieving the objectives of the organization concerned, without coordination or well coordinated, it is impossible for a job to achieve the expected results.

Work in any organization before it is practiced or done, the employees in addition to knowing the main duties and functions must also pay attention to the direction or exhortation of superiors which can help the employees think in work. Thus, it is expected that the quality of the work produced by the Tanah Bumbu Regency Election Commission can be accepted by the elements in the organization in order to increase the work target / target more optimally in the future.

In addition, in carrying out its work employees must do it in accordance with accurate data and information concerning the organization concerned is also very instrumental in supporting the achievement of optimal quality of work. With accurate data and information, the target / target and objectives of the organization can be achieved.
Employees who are equipped with knowledge in carrying out their work can affect the quality of work produced and with the knowledge possessed, based on their respective duties will support the implementation of tasks in their positions professionally and with a wide knowledge an employee is expected to be able to do a good job and productive. Because with the knowledge in accordance with the field and work done by the employees can help in the process of completion of work. Where knowledge is the accumulation of educational process results, both formally and nonformally obtained that contribute to a person in the prevention of problems, copyright is included in doing or completing work.

Employees need to be empowered to apply their skills and abilities, especially in anticipation of changes [7]. Education and training are also part of the human resource development investment, the longer a person spends in education and training the more advanced his ability or competence and knowledge in doing work and thus the higher his performance.

Third, punctuality. Punctuality is the completion of a job. Where timely means public services can be completed within a predetermined time. Basically a measure of punctuality measure whether an individual doing what is said to be done. The value at which a job can be carried out in accordance with a set time, or at a time earlier than this time is also one of the factors a job can be completed in accordance with the previously planned time. Related to that, in an organization, we must know how a job done by employees can be completed in time.

Tanah Bumbu Regency Election Commission has been serious enough in doing their work and trying to complete it on time because each employee / individual already has a job description that contains about the obligations and accountability of employees to their duties and functions even though admittedly there are still some employees who are less serious in completing their duties. Therefore, it is necessary to improve the discipline of employees in terms of completing their work on time, even before the need for the work so that it can achieve the organization's work targets that have been set.

In addition, to be able to improve the performance of the organization, each employee is required to complete the work / task when needed or if necessary the work is completed before it is needed so that employees can pursue other tasks so as to efficiently time the existing.

The constraints in achieving the performance of the secretariat apparatus of the Tanah Bumbu Regency Election Commission, as follows, are: 
First, discipline employees. That the discipline of the electoral commission in Tanah Bumbu district has not met expectations, there are employees who are not disciplined so that the completion of the duties and responsibilities given is often not efficient.

In a disciplined organization shows a condition or the respect that exists in the employee to the rules and accuracy of the organization. Discipline includes obedience and respect for agreements made between organizations and employees. Which is where this discipline concerns the behavior of the employees themselves. The obedience of employees in respecting the rules of the organization was working can encourage an employee to work better because with discipline created by itself, the employee will be comfortable working in the organization.

Second, efficiency. The work of the employees of the Election Commission of Tanah Bumbu Regency is right on the target and objectives of the organization but not yet maximal. This is due to the condition of the region, climate, and infrastructure that has so that in terms of efficiency there are obstacles in achieving the target. Efficiency relates to the number of sacrifices spent in an effort to achieve the objectives of the organization. An organization can be said to be efficient when it includes merging optimal work processes and designs of equipment and other physical facilities based on work activities that include procedures, arrangements and standards of organizational work.

Factors of inefficiencies in the tendency to swell bureaucracy, both in the sense of structure and breadth of interfering with people's lives [8] or weaknesses inherent in employees such as technical ability, namely the lack of ability to skillfully perform tasks, both routine, and developmental [9].

\section{CONCLUSION}

Based on the results and discussions above, the conclusion of the performance assessment of the secretariat apparatus of the Tanah Bumbu Regency Election Commission includes the criteria of quantity, quality and timing as well as the constraints on discipline factors and efficiency factors.

\section{REFERENCES}

1. Sintha, E. O. M., Suryadi, B., \& Syafari, M. R. (2020). Performance Assessment of Local Government Organizations on Flood Disaster Prevention and Preparedness in Gunung Mas Regency. Scholars International Journal of Law, Crime and Justice, 3(12):458-462.

2. Lenvine, C. H (1990). Public Administration: Chalenges, Choices, Consequences. Illinois: Scott Foreman.

3. Dharma, A. (2004). Manajemen Supervisi. Jakarta: Rajawali Press.

4. Sikula, A. E. (1981). Training dan Pengembangan Tenaga Kerja. Jakarta: Pustaka Binaman.

5. Moleong, L. (2013). Metode Penelitian Kualitatif: Edisi Revisi. Bandung: PT Remaja Rosdakarya.

6. Miles, M. B., \& Huberman. (1984). A Qualitative Data Analysis: A Sourcebook of New Method. London: Sage Publications Inc.

7. Popovich, G. M. (1998). Creating-Performance Government Organization, Michigan: Wiley.

8. Tjokroamidjojo, B. (1995). Pengantar Administrasi Pembangunan. Jakarta: LP3ES.

9. Siagian, S. P. (2014). Manajemen Sumber Daya Manusia. Jakarta: Bumi Aksara. 